\title{
Task 3.13 - Hot-Gas Filter Testing
}

\author{
Semi-Annual Report \\ July 1 - December 31, 1995 \\ RECEIVED \\ Allf 121997 \\ OSTI \\ By \\ Michael L. Swanson
}

Work Performed Under Contract No:: DE-FC21-93MC30097

\author{
For \\ U.S. Department of Energy \\ Office of Fossil Energy \\ Federal Energy Technology Center \\ Morgantown Site \\ P.O. Box 880 \\ Morgantown, West Virginia 26507-0880
}

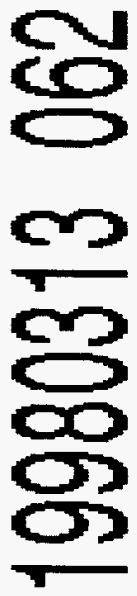

By

Energy Environmental Research Center University of North Dakota P. O. Box 9018

Grand Forks, North Dakota 58202-9018

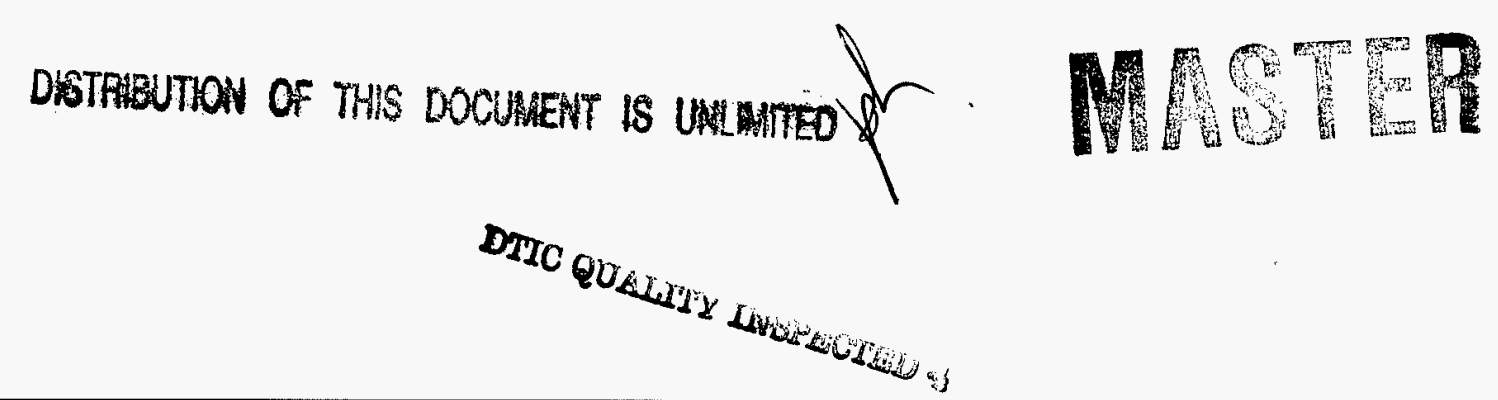




\section{Disclaimer}

This report was prepared as an account of work sponsored by an agency of the United States Government. Neither the United States Government nor any agency thereof, nor any of their employees, makes any warranty, express or implied, or assumes any legal liability or responsibility for the accuracy, completeness, or usefulness of any information, apparatus, product, or process disclosed, or represents that its use would not infringe privately owned rights. Reference herein to any specific commercial product, process, or service by trade name, trademark, manufacturer, or otherwise does not necessarily constitute or imply its endorsement, recommendation, or favoring by the United States Government or any agency thereof. The views and opinions of authors expressed herein do not necessarily state or reflect those of the United States Government or any agency thereof. 


\section{DISCLAIMER}

This report was prepared as an account of work sponsored by an agency of the United States Government. Neither the United States Government, nor any agency thereof, nor any of their employees makes any warranty, express or implied, or assumes any legal liability or responsibility for the accuracy, completeness, or usefulness of any information, apparatus, product, or process disclosed or represents that its use would not infringe privately owned rights. Reference herein to any specific commercial product, process, or service by trade name, trademark, manufacturer, or otherwise does not necessarily constitute or imply its endorsement, recommendation, or favoring by the United States Government or any agency thereof. The views and opinions of authors expressed herein do not necessarily state or reflect those of the United States Government or any agency thereof.

\section{ACKNOWLEDGMENT}

This report was prepared with the support of the U.S. Department of Energy (DOE), Morgantown Energy Technology Center, Cooperative Agreement No. DE-FC21-93MC30097. However, any opinions, findings, conclusions, or recommendations expressed herein are those of the author(s) and do not necessarily reflect the views of the DOE.

\section{EERC DISCLAIMER}

LEGAL NOTICE This research report was prepared by the Energy \& Environmental Research Center (EERC), an agency of the University of North Dakota, as an account of work sponsored by the U.S. Department of Energy. Because of the research nature of the work performed, neither the EERC nor any of its employees makes any warranty, express or implied, or assumes any legal liability or responsibility for the accuracy, completeness, or usefulness of any information, apparatus, product, or process disclosed, or represents that its use would not infringe privately owned rights. Reference herein to any specific commercial product, process, or service by trade, trademark, manufacturer, or otherwise does not necessarily constitute or imply its endorsement or recommendation by the EERC. 
TABLE OF CONTENTS

LIST OF FIGURES $\ldots \ldots \ldots \ldots \ldots \ldots \ldots \ldots \ldots \ldots \ldots \ldots$ i

LIST OF TABLES $\ldots \ldots \ldots \ldots \ldots \ldots \ldots \ldots \ldots \ldots \ldots \ldots \ldots \ldots$ i

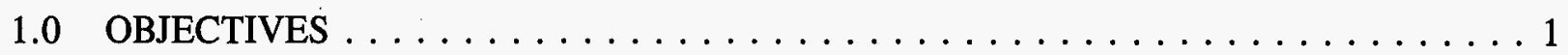

2.0 BACKGROUND INFORMATION $\ldots \ldots \ldots \ldots \ldots \ldots \ldots \ldots \ldots \ldots$

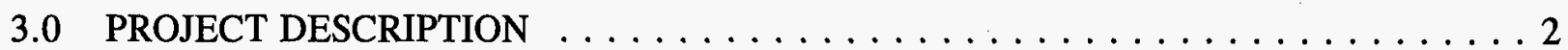

3.1 Hot-Gas Filter Vessel (HGFV) . . . . . . . . . . . . . . . . 5

3.2 High-Pressure and High-Temperature Sampling System $\ldots \ldots \ldots \ldots \ldots$

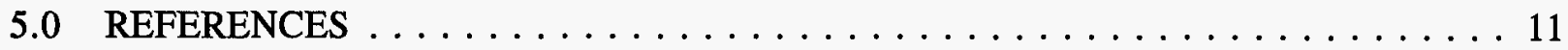

\section{LIST OF FIGURES}

1 TRDU and hot-gas filter vessel in the EERC gasification tower. . . . . . . . . 3

2 Schematic of the filter vessel design with internal refractory, tube sheet, and shroud. $\ldots \ldots 7$

\section{LIST OF TABLES}

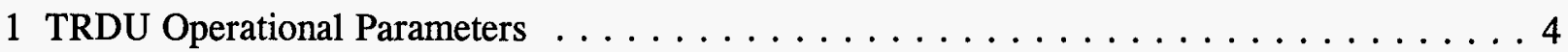

2 Design Criteria for the Pilot-Scale Hot-Gas Filter Vessel . . . . . . . . . . . . . 5

3 Analysis of TRDU Slag, Bed Material, and Hard and Soft Refractory $\ldots \ldots \ldots \ldots$ 


\section{TASK 3.13 - HOT-GAS FILTER TESTING}

\subsection{OBJECTIVES}

The objectives of the hot-gas cleanup (HGC) work on the transport reactor demonstration unit (TRDU) located at the Energy \& Environmental Research Center (EERC) is to demonstrate acceptable performance of hot-gas filter elements in a pilot-scale system prior to long-term demonstration tests. The primary focus of the experimental effort in the 2-year project is the testing of hot-gas filter element performance (particulate collection efficiency, filter pressure differential, filter cleanability, and durability) as a function of temperature and filter face velocity during short-term operation (100-200 hours). The filter vessel is used in combination with the TRDU to evaluate the performance of selected hot-gas filter elements under gasification operating conditions. This work directly supports the power systems development facility (PSDF) utilizing the M.W. Kellogg transport reactor located at Wilsonville, Alabama (1) and, indirectly, the Foster Wheeler advanced pressurized fluid-bed combustor, also located at Wilsonville $(2,3)$.

\subsection{BACKGROUND INFORMATION}

The U.S. Department of Energy (DOE) Morgantown Energy Technology Center (METC) has a HGC program intended to develop and demonstrate gas stream cleanup options for use in combustion- or gasification-based advanced power systems. One objective of the METC HGC program is to support the development and demonstration of barrier filters to control particulate matter. The goal is not simply to meet current New Source Performance Standards (NSPS) with respect to particulate emissions, but also to protect high-efficiency gas turbines and control particulate emissions to low enough levels to meet more stringent regulatory requirements anticipated in the future. DOE/METC is investing significant resources in the PSDF under a Cooperative Agreement with Southern Company Services, Inc. (SCS). The Wilsonville facility will include five modules, including an advanced gasifier module and a HGC module. The gasifier module incorporates the M.W. Kellogg transport reactor technology for both gasification and combustion $(4,5)$. Several other demonstration-scale advanced power systems also utilizing hotgas particulate cleanup technology will benefit indirectly from this research. These systems include the Clean Coal IV Piñon Pine IGCC Power Project located at the Sierra Pacific Power Company's Tracy Station near Reno, Nevada.

The TRDU was built and operated at the EERC under Contract No. C-92-000276 with SCS. The M.W. Kellogg Company designed and procured the reactor and provided valuable on-site personnel for start-up and during operation. The Electric Power Research Institute (EPRI) was involved in establishing the program and operating objectives with the EERC project team.

The purpose of the previous program was to build a reactor system larger than the transport reactor test unit (TRTU) located in Houston, Texas, in support of the Wilsonville PSDF transport reactor train. The program was to address design and operation issues for the Wilsonville unit and also help develop information on the operation of the unit to decrease start-up costs. 
The TRDU (200-lb/hr coal-limestone feed rate) now provides an intermediate scale to the TRTU (up to $10-\mathrm{lb} / \mathrm{hr}$ coal-limestone feed rate) and the Wilsonville Transport Reactor (3400-lb/hr feed rate). Some of the design, construction, start-up, and operational issues for the Wilsonville transport train are being addressed during this project.

Five test periods were completed in the TRDU using Wyodak subbituminous coal. These were shakedown tests, which included cold and hot solids circulation, coal combustion, and coal gasification. The TRDU operated under solids circulation for a period of $256 \mathrm{hr}$, coal combustion for $46.5 \mathrm{hr}$, and coal gasification for $34 \mathrm{hr}$. Data from four steady-state gasification periods (a total of approximately $18 \mathrm{hr}$ ) were analyzed $(6,7)$.

The four major design criteria that were established by EPRI were met. These included coal feed rate, operating pressure, carbon conversion, and high heating value of the product gas. Major accomplishments included showing that the TRDU performed well hydrodynamically, that it had the ability to switch from combustion mode to gasification mode easily and safely, that solids could be fed to and removed from the system, and that the J-leg/standpipe and cyclone performed according to their design specifications. The staged char combustion mixing zone design was not verified because of the lack of nonvolatile char and a reduced operational schedule. This resulted in oxygen breakthrough from the mixing section into the riser as a result of insufficient carbon inventory in the circulating solids.

\subsection{PROJECT DESCRIPTION}

This program has a phased approach involving modification and upgrades to the TRDU and the fabrication, assembly, and operation of a hot-gas filter vessel (HGFV) capable of operating at the outlet design conditions of the TRDU, a $200-300-\mathrm{lb} / \mathrm{hr}$ pressurized circulating fluid-bed gasifier similar to the gasifier being tested at the Wilsonville facility. The TRDU has an exit gas temperature of up to $980^{\circ} \mathrm{C}\left(1800^{\circ} \mathrm{F}\right)$, a gas flow rate of $300 \mathrm{scfm}$, and an operating pressure of 120-150 psig. Phase I includes upgrading the TRDU based upon past operating experiences. Additions will include a nitrogen supply system upgrade, upgraded LASH (lime ash) auger and coal feed lines, a second pressurized coal feed hopper, and a dipleg ash hopper and modifications to spoil the performance of the primary cyclone.

The TRDU system can be divided into three sections: the coal feed section, the TRDU, and the product recovery section. The TRDU proper, as shown in Figure 1, consists of a riser reactor with an expanded mixing zone at the bottom, a disengager, and a primary cyclone and standpipe. The standpipe is connected to the mixing section of the riser by a J-leg transfer line. All of the components in the system are refractory-lined and designed mechanically for 150 psig and an internal temperature of $1090^{\circ} \mathrm{C}\left(2000^{\circ} \mathrm{F}\right)$. Table 1 summarizes the operational performance for the TRDU under the previous test program (6).

The premixed coal and limestone feed to the transport reactor can be admitted through three nozzles, which are at varying elevations. Two of these nozzles are located near the top of the mixing zone (gasification), and the remaining one is near the bottom of the mixing zone (combustion). During operation of the TRDU, feed is admitted through only one nozzle at a time. 


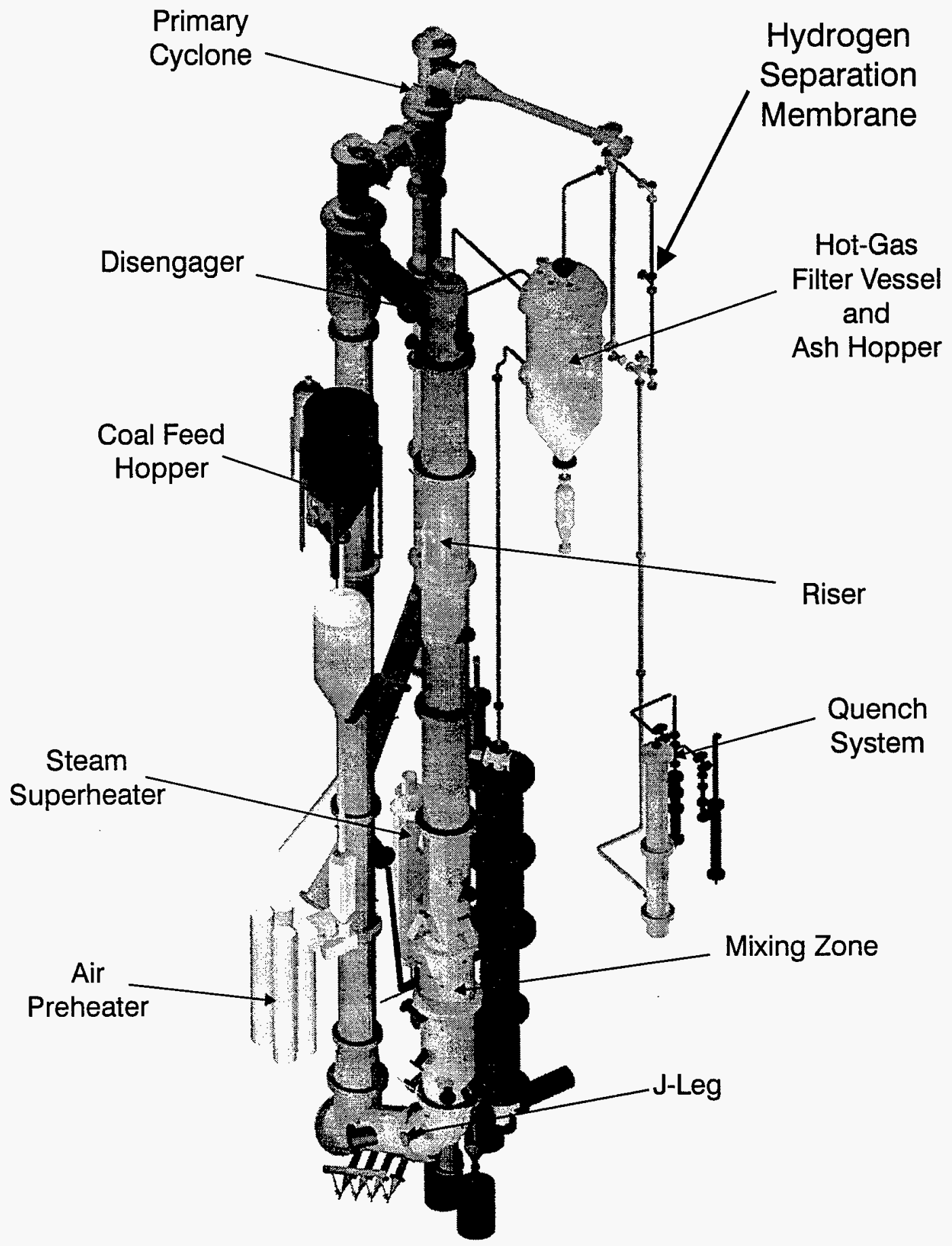

EERC MS12573..CDR

Figure 1. TRDU and hot-gas filter vessel in the EERC gasification tower. 


\section{TABLE 1}

TRDU Operational Parameters

\begin{tabular}{lc} 
Parameter & $\begin{array}{c}\text { Actual } \\
\text { Operating } \\
\text { Condition }\end{array}$ \\
\hline Coal & Wyodak \\
Moisture Content, \% & 20 \\
Pressure, psig & $117-122$ \\
Steam:Coal Ratio & 0.38 \\
Air:Coal Ratio & $3.5-4.7$ \\
Ca:S Ratio, mole & 1.5 \\
Air Inlet Temperature, ${ }^{\circ} \mathrm{C}$ & 425 \\
Steam Preheat, ${ }^{\circ} \mathrm{C}$ & 390 \\
Coal Feed Rate, lb/hr & 173 \\
Gasifier Temperature, maximum ${ }^{\circ} \mathrm{C}$ & 850 \\
$\Delta \mathrm{T}$, maximum ${ }^{\circ} \mathrm{C}$ & 121 \\
Conversion, $\%$ & 96 \\
High Heating Value of Fuel Gas, Btu/scf & 104 \\
Heat Loss as Coal Feed, $\%$ & 27 \\
Riser Velocity, ft/sec & $28-30$ \\
Heat Loss, Btu/hr & $420,000^{2}$ \\
Standpipe Superficial Velocity, ft/sec & $0.4-0.54$ \\
\hline${ }^{1}$ Steady-state conditions were not achieved. & \\
${ }^{2}$ Estimated heat loss; steady-state conditions were not achieved. &
\end{tabular}

The coal feed is measured by an rpm controlled metering auger. Oxidant is fed to the reactor through two pairs of nozzles at varying elevations within the mixing zone. For the combustion mode of operation, additional nozzles are provided in the riser for feeding secondary air. Hot solids from the standpipe are circulated into the mixing zone, where they come into contact with the oxidant and the steam being injected into the J-leg. This feature enables spent char to contact oxidant and steam prior to the fresh coal feed. This staged gasification process is expected to enhance the process efficiency. Gasification or combustion and desulfurization reactions are carried out in the riser as coal, sorbent, and oxidant (with steam for gasification) flow up the tube. The solids circulation into the mixing zone is controlled by the solids level in the standpipe.

The riser, disengager, standpipe, and cyclones are equipped with several internal and skin thermocouples. Nitrogen-purged pressure taps are also provided to record differential pressure across the riser, disengager, and the cyclones. The bulk of entrained solids leaving the riser is separated from the gas stream in the disengager and circulated back to the riser via the standpipe. 
A solids stream is withdrawn from the standpipe via an auger to maintain the system's solids inventory. Gas exiting the disengager enters a primary cyclone that has been modified to provide variable particulate collection performance. Solids from diplegs of the primary cyclone are collected in a lock hopper. Gas exiting this cyclone enters a jacketed-pipe heat exchanger before entering the HGC filter vessel. The cleaned gases leaving the HGC filter vessel enter a quench system before being depressurized and vented to a flare.

The quench system uses a sieve tower and two direct-contact water scrubbers to act as heat sinks and remove impurities. All water and organic vapors are condensed in the first scrubber, with the second scrubber capturing entrained material and serving as a backup. The condensed liquid is separated from the gas stream in a cyclone that also serves as a reservoir. Liquid is pumped either to a shell-and-tube heat exchanger for reinjection into the scrubber or down to the product receiver barrels.

\subsection{Hot-Gas Filter Vessel (HGFV)}

Subtask 3.13 - Hot-Gas Filter Testing is a new hot-gas filter program started in January 1995 as an addition to the METC Cooperative Agreement. First-year funding made available in March 1995 has supported upgrades to the TRDU, installation of the new filter vessel and new inlet-outlet piping requirements and the first of three 200-hour filter tests. The filter design criteria are summarized in Table 2 and a schematic is given in Figure 2.

This vessel is designed to handle all of the gas flow from the TRDU at its expected operating conditions. The vessel is approximately $48 \mathrm{in.} \mathrm{ID} \mathrm{and} 185 \mathrm{in}$. long and is designed to handle gas flows of approximately $325 \mathrm{scfm}$ at temperatures up to $980^{\circ} \mathrm{C}\left(1800^{\circ} \mathrm{F}\right)$ and $130 \mathrm{psig}$. The refractory has a 28 -in. ID with a shroud diameter of approximately 22 in. The vessel is sized such that it could handle candle filters up to $1.5 \mathrm{~m}$ long; however, $1-\mathrm{m}$ candles are currently being utilized in the initial $540^{\circ} \mathrm{C}\left(1000^{\circ} \mathrm{F}\right)$ gasification tests. Candle filters are 2.375 in. OD with a 4inch center line-to-center line spacing.

TABLE 2

Design Criteria for the Pilot-Scale Hot-Gas Filter Vessel

\begin{tabular}{lc}
\hline Range of Operating Conditions & \\
Inlet Gas Temperature & $540^{\circ}-980^{\circ} \mathrm{C}\left(1000^{\circ}-1800^{\circ} \mathrm{F}\right)$ \\
Operating Pressure & $120-150 \mathrm{psig}$ \\
Volumetric Gas Flow & $325 \mathrm{scfm}$ \\
Number of Candles & $19(1-$ or $1.5-\mathrm{m})$ \\
Candle Spacing & 4.0 in. $\Phi$ to $\Phi$ \\
Filter Face Velocity & $2.5-10 \mathrm{ft} / \mathrm{min}$ \\
Particulate Loading & $<10,000 \mathrm{ppm}$ \\
Temperature Drop Across HGFV & $<30^{\circ} \mathrm{C}\left(50^{\circ} \mathrm{F}\right)$ \\
Nitrogen Backpulse System & Unheated \\
\hline
\end{tabular}




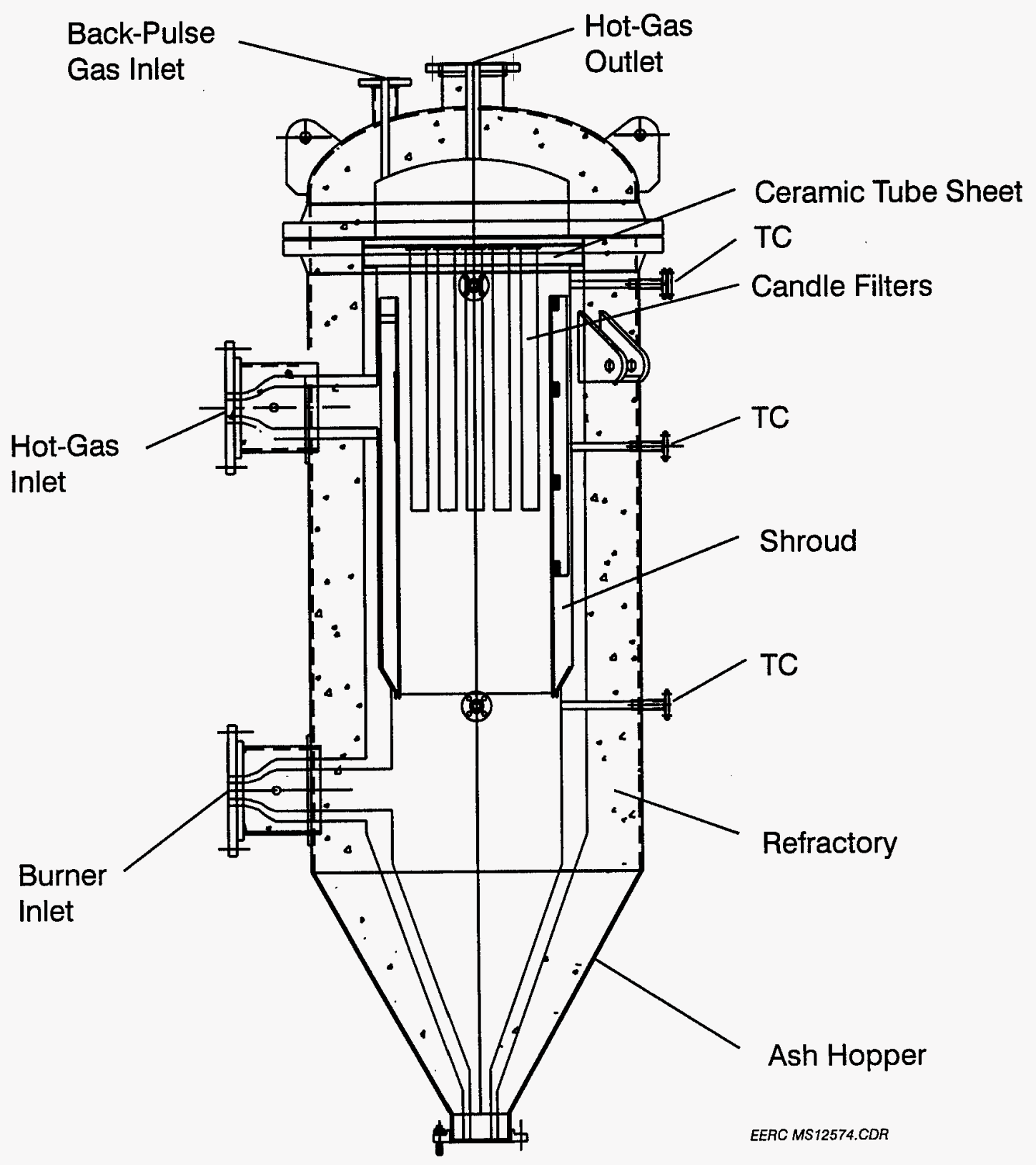

Figure 2. Schematic of the filter vessel design with internal refractory, tube sheet and shroud. 
The total number of candles that can be mounted in the current geometry of the HGFV tube sheet is 19. This enables filter face velocities as low as $2.5 \mathrm{ft} / \mathrm{min}$ to be tested. Phases III through $V$ consist of 200-hr hot-gas filter tests under gasification conditions using the TRDU with the HGC operating at temperatures of $540^{\circ}-650^{\circ} \mathrm{C}\left(1000^{\circ}-1200^{\circ} \mathrm{F}\right), 120 \mathrm{psig}$, and increasing face velocities for each test. Higher face velocities would be achieved by using fewer candles. The approved test matrix will perform the first test at $540^{\circ}-650^{\circ} \mathrm{C}\left(1000^{\circ}-1200^{\circ} \mathrm{F}\right), 120 \mathrm{psig}, 2.7 \mathrm{ft} / \mathrm{min}$ face velocity. The second test will remove six candles to increase the face velocity to approximately $4.5 \mathrm{ft} / \mathrm{min}$ at the same operating temperature and pressure. The openings for the six removed candles will simply be blanked off. If this test is successful, the third test will remove another six candles, seal off the candle openings, and repeat the procedure. The filter face velocity would increase up to $7.5 \mathrm{ft} / \mathrm{min}$ This program is currently testing seven Industrial Filter \& Pump (IF\&P) Fibrosic candles along with their ceramic tube sheet, six silcon carbon ceramic fiber candles from the $3 \mathrm{M}$ company, along with one metal (iron aluminide) and five Vitropore silcon carbon ceramic candles from Pall Advanced Separation Systems Corporation.

Ports were added in the filter vessel to allow temperature and pressure measurements to be obtained and the insertion of a water-cooled borescope probe for inspecting candle filters off-line. The ash letdown system consists of two sets of alternating high-temperature valves with a conical pressure vessel to act as a lock hopper. Additionally, a preheat natural gas burner attached to a separate gasifier is used to preheat the filter vessel separately from the TRDU while the gasifier is starting up. The hot gas from the burner enters the vessel via a nozzle inlet separate from the dirty gas.

The high-pressure nitrogen backpulse system is capable of backpulsing up to four sets of four or five candle filters with ambient-temperature nitrogen in a time-controlled sequence. The pulse length and volume of nitrogen displaced into the filter vessel is controlled by regulating the pressure (up to $800 \mathrm{psig}$ ) of the nitrogen reservoir and the solenoid valves used to control the timing of the gas pulse. Figure 1 also shows the filter vessel location and process piping in the EERC gasifier tower. Since the first series of gasification tests is to be completed in the $540^{\circ}-650^{\circ} \mathrm{C}\left(1000^{\circ}-1200^{\circ} \mathrm{F}\right)$ range, a length of heat exchanger is used to drop the gas temperature to the desired range. Inserting an existing set of high-temperature valves in the fuel gas heat exchanger will allow bypassing the filter vessel during start-up and shakedown of the TRDU and switching to the preheated filter vessel when steady-state conditions are achieved. In addition, sample ports for obtaining particulate and hazardous air pollutant (HAP) samples have been constructed.

TRDU operation and filter element testing will benefit other ongoing projects at the EERC. The first sampling and analysis activities will be conducted to generate hazardous air pollutant data concerning trace metal transformations, speciation of mercury, and metal concentrations at selected points within the TRDU and HGC in support of a project entitled "Trace Element Emissions" funded by METC. In addition, materials and ash data concerning the high-temperature filter media and ash interactions will be collected in support of a project entitled "Hot-Gas Filter Ash Characterization" jointly funded by METC and EPRI. While the cost of this specific data collection will be covered by the individual projects, the synergy that results from the integration of these projects will minimize the cost of collecting this information for all involved projects. 


\subsection{High-Pressure and High-Temperature Sampling System}

The high-pressure and high-temperature sampling system (HPHTSS) was designed and constructed to extract dust-laden flue gas isokinetically from either an oxidizing or reducing environment. The maximum gas temperature at which the sample probe can be operated is specified as $980^{\circ} \mathrm{C}\left(1800^{\circ} \mathrm{F}\right)$ for the HPHTSS. The maximum working pressure of the gas stream for the HPHTSS is specified as 150 psig.

The probe for the HPHTSS is a $3 / 8$-in.-OD and 1/8- in.-ID 304 stainless steel tube. The probe is used for only one sampling test and then discarded. The key to the sampling system is the use of a vessel designed to withstand high-pressure and high-temperature conditions to enclose the low- pressure sampling devices.

The vessel was constructed of 5 -in. Schedule 80 pipe and fitted with raised-face 300-lb flanges. The material used for the HPHTSS pressure vessel was 316L stainless steel. The HPHTSS was designed to house both multicyclone assemblies with backup filter and a backup filter alone.

The principle of operation is to pressurize the outside of the sampling device (i.e., multicyclone assembly or backup filter) with nitrogen at a slightly higher gas pressure than the system pressure of the flue gas. The pressure differential between the nitrogen gas within the pressure vessel and the flue gas within the sampling device is maintained at less than 5 psig.

If the HPHTSS is operating in a reducing environment where the presence of organic vapors is a possibility, the pressure vessel is capable of operating at temperatures as high as $540^{\circ} \mathrm{C}$ $\left(1000^{\circ} \mathrm{F}\right)$ and maintaining nitrogen gas pressures up to $150 \mathrm{psig}$. This will prevent the heavier organic vapors from condensing while passing through the particulate sampling assembly. Electric resistance heaters will be used to heat the pressure vessel to specified temperatures.

Once the process gas exits the sampling assembly, the gas pressure is reduced through a throttling valve to approximately atmospheric pressure. The throttling valve will also act as the flow control valve for the sampling system. A second throttling valve was installed in series in the event that the primary throttling valve fails to close.

After the throttling valve, the process gas is cooled through a set of impingers to remove moisture and organic vapors if present. A set of up to six impingers may be used in this sampling system. These impingers are rated for $200 \mathrm{psig}$ at $120^{\circ} \mathrm{C}\left(250^{\circ} \mathrm{F}\right)$ maximum operating conditions. The impingers are made of 304 stainless steel, with the interior surfaces coated with Teflon. The Teflon-coated surfaces allow the HPHTSS to be used for trace metal sampling.

The dry gas is then metered through a rotometer and dry-gas meter to measure total flow before it is vented out the stack. 


\subsection{ACCOMPLISHMENTS}

During the July through October months, design, construction, and installation of the HGFV, its internal components, and all the auxiliary equipment such as the nitrogen backpulse system and the TRDU inlet, outlet, and bypass product gas piping was completed. Testing of individual components was also completed and start-up of the TRDU was attempted in mid-November. However, operational problems with the Windows ${ }^{\mathrm{TM}}$-based data acquisition and control software lead to the shutdown the TRDU before any solids were circulated or coal was fed to the system. These problems were overcome by running a DOS ${ }^{\mathrm{TM}}$-based version of the data acquisition software as a blind node, with the computers with the Windows ${ }^{\mathrm{TM}}$-based versions networked to the blind node to allow process input/output to the control system.

The TRDU was next operated for a week in mid-December. The system was shut down prematurely when solids circulation could not be reestablished after a disruption in the coal feed. The test chronology and highlights are summarized as follows:

\section{Chronology of Events}

Started solids circulation - Run Hour 0

Started natural gas burner - Run Hour 0.5

Started coal feed (combustion) - Run Hour 9.0

Started gasification - Run Hour 16.5

Lost coal feed - Run Hour 17.5

Started natural gas burner - Run Hour 17.75

Cleared coal feed - Run Hour 18

Solids circulation could not be reestablished.

Burner shut off and run terminated - Run Hour 21

\section{Test Highlights}

- 18 hours of solids circulation, 7.5 hours of combustion, and 1 hour of gasification were accumulated. All aspects of the system operated smoothly during this 18 -hour period.

- The system was brought to the gasification mode in 17 hours. Previously, it took over 48 hours to get to the same point in operation.

- All auxiliary systems that previously caused unscheduled shutdowns operated without problems, including the nitrogen tank farm, process control system, coal feed system, ash auger drain, and solids fill system.

- The HGFV was brought up to temperature on clean gas from the carbonizer and was on stand-by mode for 38 hours at temperature. No dirty gas was passed through the filter vessel during the test.

- Experience and data were obtained that can be used for the Willsonville start-up. 


\section{Observed Operational Problems During TRDU Test}

Coal was prepared in November and stored outside in transfer hoppers and then transferred to the main feed hoppers for the TRDU just prior to start-up. Because of condensation, moisture had accumulated in the bottom cone of the transfer hopper. When coal was charged to the feed hoppers, this wet coal caused the plug in the coal feed line. When other hoppers were checked, it was determined that approximately 5 gallons of coal in the bottom of the transfer hoppers was wet. This can be easily removed and will be incorporated into our operational procedures. The condensed moisture would not be a problem if coal were prepared immediately before charging to the hopper rather than in advance. The coal in the first feed hopper had been charged in November right after it had been prepared. Feed from this hopper was very smooth.

Examination of the run data indicated that when the burner was restarted after the loss of coal feed, there were some temperature excursions in the burner area and the bottom mixing section. Temperature was alarmed for approximately 48 seconds in this area while work was being done on the coal feed line. The temperatures went out of alarm after that 48-second interval. Run data also indicated that the burner stoichiometry was lower than normal.

Once it was determined that circulation could not be reestablished, the bottom section was removed. The bottom of the mixing section was plugged with slagged fly ash and refractory. This plug originated at about the point where the burner air entered into the riser section and extended about 2 feet. Samples of the slag material were removed for analysis. Their major element compositions, along with the compositions of the hard and soft refractories as given by the suppliers, are listed in Table 3 on a weight percent oxide basis.

TABLE 3

Analysis of TRDU Slag, Bed Material, and Hard and Soft Refractory

\begin{tabular}{lcccc}
\hline Oxide (wt\%) & Slag & Bed & Hard & Soft \\
\hline $\mathrm{SiO}_{2}$ & 38 & 43 & 37 & 44 \\
$\mathrm{Al}_{2} \mathrm{O}_{3}$ & 26 & 20 & 56 & 40 \\
$\mathrm{Fe}_{2} \mathrm{O}_{3}$ & 2.4 & 2.7 & 0.7 & 0.6 \\
$\mathrm{CaO}$ & 22 & 25 & 5.5 & 11 \\
$\mathrm{MgO}$ & 8.7 & 6.7 & 0.2 & 0.3 \\
\hline
\end{tabular}

Analysis of the slag grab sample indicates that it is composed primarily of molten bed material with some refractory. Assuming that equal amounts of hard and soft refractory dissolved into the slag, then the composition of the grab sample suggests that the slag is composed of around $80 \%$ bed material and $20 \%$ refractory. Phase diagrams of the $\mathrm{CaO}-\mathrm{MgO}-\mathrm{Al}_{2} \mathrm{O} 3-\mathrm{SiO}_{2}$ system indicate that the minimum temperature at which this composition would be expected to be molten is around $2300^{\circ} \mathrm{F}$; thus the material must have reached at least that temperature. Separate 
measurements of the viscosity of slag collected from a power plant burning Rochelle coal indicate that the ash is relatively sticky above approximately $2050^{\circ} \mathrm{F}$ in a reducing environment, although individual particles may be sticky at even lower temperatures.

A portion of the refractory in the burner area was melted away. The melted refractory was in the burner area and did not extend into the mixing area. A minimal amount of ash was mixed with the refractory in this area, as indicated by chemical analysis of the slag, refractory, and coal ash. It is obvious that the temperature in this area exceeded the melting point of the refractory. The refractory in the burner section was chosen for its insulating capabilities and has a relatively low melting point $\left(2000^{\circ} \mathrm{F}\right)$. Under the normal mode of operation, the burner temperature is kept below $1800^{\circ} \mathrm{F}$ while the heat is quickly and efficiently removed from the burner area by the recirculating solids.

The layered ash buildup on the walls of the mixing section possibly could have occurred during the 17.5 hours of operation prior to the loss of coal feed or it may have been the result of overheating the refractory to the point where the refractory in the burner region became molten enough to flow into the mixing zone and capture ash on its sticky surface. The inner core of the ash plug had been exposed to high temperatures, as evidenced by its physical appearance and by mineralogical analysis.

\section{Plans for Mitigating Problems in Future Tests}

- Repour the burner section with a lower-insulating, higher-temperature refractory

- Consider startup with alumina rather than coal ash

- Consider switching to a coal with a higher ash fusion temperatures

- Alter operating procedures

- Temperature control/burner shutoff at lower temperatures and higher burner failure stoichiometry

- Additional thermocouples in the burner/mixing zone

- Initiate coal feed at a lower temperature and turn off the burner earlier during start-up

- Heat up the system at a slower rate-transition to gasification after 25 to 30 hours.

- Continue the following procedures already in place:

- Watch trending of differential pressure in the mixing zone for early indications of ash buildup

- Examine LASH drain material for evidence of ash agglomeration

- Check all coal hoppers after they have been moved in to the warm gasification tower, and remove wet coal prior to charging the feed hoppers on the TRDU

\subsection{REFERENCES}

1. Ness, R.O. “Transport Reactor Demonstration Unit," In Proceedings of the Coal-Fired Power Systems 93 - Advances in IGCC and PFBC Review Meeting; DOE/METC-93/6131 (DE93000289), June 1993; pp 357-358.

2. Sears, R.E.; Griswald, G.H.; Boyd, T.J.; Fankhanel, M.O.; Crumm, C.J.; Pontius, D.H. "Power Systems Development Facility, PFBC System Perspectives," In Proceedings of the 
Coal-Fired Power Systems 93 - Advances in IGCC and PFBC Review Meeting; DOE/METC-93/6131 (DE93000289), June 1993; pp 121-128.

3. Rush, R.E.; Moore, D.L.; Haq, Z.U.; Pinkston, T.E.; Vimalchand, P.; McClung, J.D.; and Quandt, M.T. "Status of the Advanced PFBC at the Power Systems Development Facility," In Proceedings of the Coal-Fired Power Systems 94 - Advances in IGCC and PFBC Review Meeting; DOE/METC-94/1008 (DE94012252), June 1994; Vol. 1, pp 127-137.

4. Sears, R.E.; Griswald, G.H.; Kastner, C.E.; Pontius, D.H. "Hot Gas Cleanup Test Facility for Gasification and Pressurized Combustion," In Proceedings of the 12th Annual Gasification and Gas Stream Cleanup Systems Contractor's Review Meeting; DOE/METC92/6128, (DE93000228), Sept. 1992; Vol. 1, pp 53-63.

5. Dahlin, R.S.; Pontius, D.H.; Haq, Z.U.; Vimalchand, P.; Brown, R.; Wheeldon, J. "Plans for Hot Gas Cleanup Testing at the Power Systems Development Facility," In Proceedings of the 13th International Conference on Fluidized Bed Combustion, May 1995; Vol. 1, pp 449-459.

6. Rush, R.E.; Fankhanel, M.O.; Campbell, W.M. “Transport Reactor Development Status," In Proceedings of the Coal-Fired Power Systems 94 - Advances in IGCC and PFBC Review Meeting; DOE/METC-94/1008 (DE94012252), June 1994; Vol. 1, pp 73-82.

7. Ness, R.O. “Transport Reactor Demonstration Unit, Volume 1 - Final Report," EERC Publication No. 95-EERC-02-06, May 1995; 150 p. 
M97002283

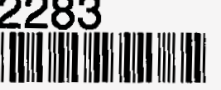

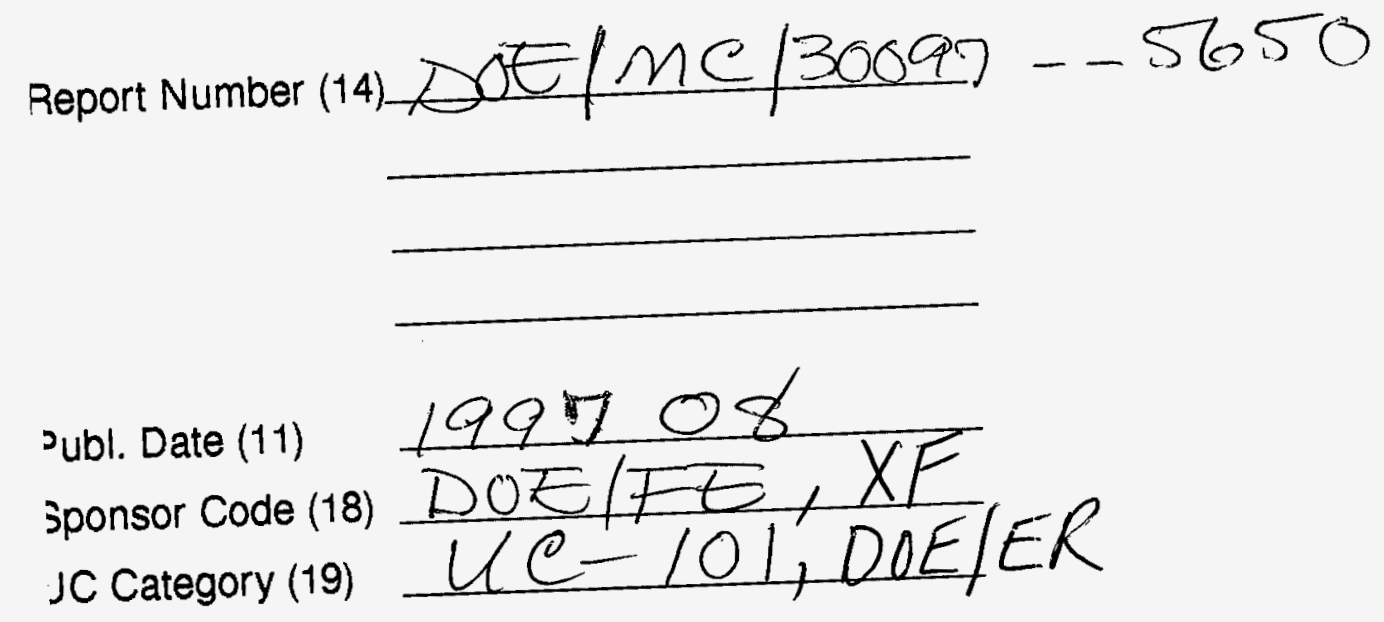

DOE 